\title{
Metabolic responses of fresh-water sunfish to seasonal photoperiods and temperatures ${ }^{1}$
}

\author{
JOHN L. ROBERTS \\ Department of Zoology, University of Massachusetts, Amberst, Massadusetts, USA
}

KURZFASSUNG: Stoffwechselreaktionen süßwasserlebender Sonnenbarsche auf jahreszeitliche Photoperioden und Temperaturen. Beim Gemeinen Sonnenbarsch Lepomis gibbosus wurden nach Adaptation an 9- und 15stündige Photoperioden und an Temperaturen zwischen $5^{0}$ und $25^{\circ} \mathrm{C}$ (Anstiegsintervalle 2,5 $\mathrm{C}$ ) im Herbst und Winter die Respirationsraten bestimmt. Es zeigte sich, daß die Temperaturadaptation der Atmung in einem bestimmten Temperaturbereich nahezu perfekt ist (Q10 etwa 1); dieser Bereich wird aber durch eine Veränderung der Tageslänge oberhalb einer kritischen Temperatur von ungefähr $10^{\circ} \mathrm{C}$ modifiziert. Innerhalb dieser Spanne thermischer Homöostasis war die Atmungsintensität von Langtag-Fischen merkbar niedriger und das Ausmaß3 der Perfektion der Anpassung etwas größer als bei den KurztagFischen. Derartige tageslängenabhängige Unterschiede wurden an Frühjahrsfischen in Brutkondition nicht gefunden. Die stoff wechselphysiologische Akklimatisation von L. gibbosus läßt sich auch an Hand der Operculumbewegungen nadweisen; sie ist hier allerdings weniger perfekt (Q10 etwa 1,3) als im Falle der Atmung und offenbar auch weniger von der Tageslänge abhängig. Unterschiede in der Atmungsintensität von Gehirn- und Kiemengewebe bei verschiedenen Tageslängen und Temperaturen scheinen nur als Folge einer Enthoppelung durch Dinitrophenol aufzutreten. Dieser Sachverhalt deutet auf Aktivitätsveränderungen einiger Komponenten der zellulären Systeme dieser Gewebe hin, welche bei der Adaptation an verschiedene Tageslängen und Temperaturen auftreten und erst nach partieller oder vollständiger Entkoppelung der oxydativen Phosphorylierung limitierend für die Stoff wechselintensität werden.

\section{INTRODUCTION}

Metabolic studies of teleosts within the present decade have begun to turn increasingly toward attempts to understand the interactions of temperature and photoperiod length upon activity. This is especially so as these physical factors alter seasonally, enforcing and triggering compensatory changes in behavior which are based most likely upon small alterations in the routing of substrates and products at both subcellular and systemic levels.

The fact that many temperate-zone fishes take their cues seasonally from the length of the daily photoperiod acting in conjunction with temperature as controlling factors for specific behavioral sequences such as breeding, changes in salinity preference and migration is now well established (Baggerman 1959, Harrington 1959, Hoar

1 This investigation was supported in whole by Public Health Service Research Grant GM 06377 from the Division of General Medical Sciences. 
1963). Generally we assume that the physiological load of these sequences in behavior occurs at times of the year when the restrictions of various limiting factors, e.g., oxygen supply and food supply, are minimal and when seasonal temperatures are moderate or well within the environmental extremes. If this is true, then it implies that there is a continuum in physiological adjustments by fishes to annual cycles of change in both of these environmental factors, and not just to temperature alone.

With specific regard to temperature, the extensive efforts of F. E. J. FRY and his students in Canada have convinced most of us that non-reproductive seasonal adjustments also are a common occurence among fishes (FRY 1958). The most extensive recent review of this subject is that of PROSSER (1962). On the other hand, experiments in which the combined effects of both temperature and photoperiod have been examined in fishes are few. The study of HOAR \& ROBERTSON (1959) has shown that limits in the thermal tolerance of goldfish can be manipulated by alterations in the length of experimental photoperiods at any time of the year except during spring breeding. Similarly, I have demonstrated that manipulations between short and long daily photoperiods alter levels of oxygen uptake by sunfish, Lepomis gibbosus, and crucian carp, Carassius carassius, (RoberTs 1961). The same may be true in the case of rainbow trout, Salmo gairdneri, which spawn in the fall (Evans et al. 1962). Only in the case of sunfish has insensitivity of respiration to photoperiod alteration during the breeding period been observed.

The general objective in my experiments with Lepomis has been to relate thermal acclimation and photoperiod adaptation of physiological activities to speciation within the genus. The primary concern of this discussion today will be to document one of the ideas basic to this general objective. This is the view that full thermal acclimation of metabolism by pumpkinseed sunfish, L. gibbosus, is dependent upon concurrent exposure of animals to seasonal day lengths.

Respiration and opercular frequency have been chosen as adaptation indicators. Recently, cardiac frequency recording has been found to be practical and provides a third adaptation index. This index has been added with the hope that combinations of various metabolically based activities may eventually enable reasonable estimates to be made of the thermodynamic cost of routine metabolism to fishes seasonally. Obviously, techniques for the simultaneous measurement of both cardiac and opercular minute volumes would be of considerable value in this regard.

\section{MATERIAL AND METHODS}

Fish care and feeding. Sunfish, L. gibbosus, were obtained by seining from ponds and streams in the vicinity of Amherst, Massachusetts. In the laboratory, the fish were held in 10 to 30 gallon aquaria equipped with recirculating filters and regulated within $\pm 0.5^{\circ} \mathrm{C}$. The fish were fed three times each week on a well-blended one to one mixture of liver brei and powdered dog chow. The food was prepared in large batches, forced into sausage casing, and tied off into convenient lengths for storage in a deep freezer until use. Feeding was suspended on the day before placement of fish into 
the respiration chambers or before dissection of the animals for metabolic studies with their tissues.

Photoperiod and temperature control. Daylengths selected and termed long and short day (Standard Time) were 15 and 9 hours at Amherst. The adaptation photoperiods were maintained at least 40 days before animals were used in the various experiments. In most cases, the fish were simultaneously acclimated to $20^{\circ} \mathrm{C}$ during this initial period of daylength control. The exceptions were fish taken during summer or winter months when the adaptation to long or to short days was considered to have been completed in their natural environments. Daylight fluorescent tubes were used as a light source and gave an intensity of 30 foot candles at the water surface of the fish tanks. Appropriate photoperiods also were maintained during respiration determinations with whole fish. The determinations ranged from 3 to 7 days during which time the fish remained continuously within the respiration chambers. Periods of 3 days were found to be sufficient for completion of acclimation by sunfish to temperatures above $17.5^{\circ} \mathrm{C}$. However, in the experiments reported here, two-week periods of acclimation were used routinely both above and below $17.5^{\circ} \mathrm{C}$.

Respiration of fish. Because the apparatus used for the determination of whole-fish respiration has undergone continuous modification in design, but not in its principle of operation, the description which follows applies to the equipment in its present form. Rates of oxygen uptake by fish have been established as milliliters of oxygen per kilogram wet weight per hour $(\mathrm{ml} / \mathrm{kg} / \mathrm{hr}$ ) from the difference between the oxygen content of the water supplied to each fish chamber and that flowing out of the chamber at a precisely known volume in one hour. At intervals of 1 hour, the outflow water from each of 8 fish chambers is by-passed in sequence for a 5 -minute period to a Beckman polarograph electrode (Model 777 system, Varian G-10 potentiometric recorder) for detection and recording of the dissolved-oxygen content. By-pass control of water sampling is maintained by programmed switching of solenoid-actuated, 2-way hose clamps at the outtlow ends of each chamber. Referencing to supply water is made in accordance with the repeating sequence, ref.-1-2-ref.-3-4-ref.-5-6-ref,-7-8-ref., and recycling continuously over as long a time period as required. During the 55-minute intervals between the periods of dissolved-oxygen sampling, the outtlow water of each chamber is directed through short lengths of rubber tubing to sampling bottles of $125 \mathrm{ml}$ in volume. The switching control is interrupted once each day at such a time that the referencing solenoid-clamp is open and supplying water to the polarograph electrode which also drains to a sampling bottle. The outflow rates from all fish chambers and the electrode are then determined and the water bottles exchanged for analysis of dissolved-oxygen content by another means as a standardization check. For routine standardization, a dissolved oxygen meter is used (Southern Analytical Ltd, type A 1672).

Flow-rate regulation of water passing through the respiration system at a constant pressure is maintained with lengths of capillary tubing attached to the inflow tubes in the rubber stoppers of the sampling bottles. The pressure $(76 \mathrm{~cm}$ water) is maintained to the supply manifold of the system by the usual spillway device equipped with particle filters and aerators to which water is delivered in excess of that required (see BLAŽKA 1958). Rates of water flow in individual experiments usually range from 0.5 
to 3.0 liters per hour and can be selected on the basis of the weight of the fish and the test temperatures used for determination of respiration rate. In all cases, flow rates should be regulated so that residual levels of oxygen in the outflow water from the fish chambers does not fall below $3 \mathrm{ml}$ oxygen per liter. This avoids the well-known depressing effect of hypoxia upon the metabolism of fish (PROSSER et al. 1957). In this

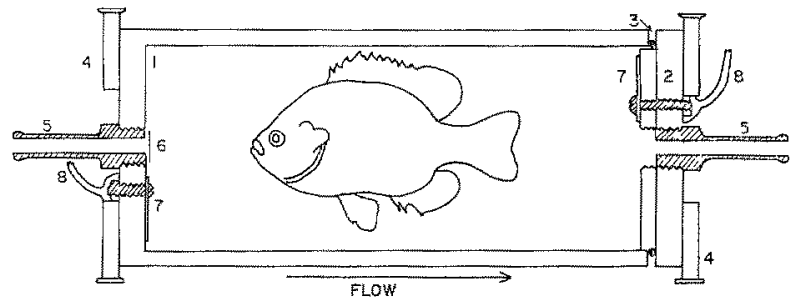

Fig. 1: Respiration chamber. Internal dimensions, $60 \mathrm{~mm}$ diameter $\times 152 \mathrm{~mm}$ long. Numerical designations are: 1) plexiglas chamber; 2) plexiglas cover; 3) " $\mathrm{O}$ " ring seal; 4) lugs for attachment of cover with rubber bands; 5) brass hose nipples; 6) baffle plate to prevent laminar

flow; 7) electrodes, $2 \mathrm{~cm}^{2}$ stainless-steel screening; 8) electrode leads, grounded shielding

system, flow rates of water have been found to vary less than 0.5 per cent over periods as long as one week providing that the fecal traps, located at the outflow ends of the animal chambers, are flushed and cleaned daily. Considerable differences have been observed in the adjustment of carp, C. carassius, and sunfish, L. gibbosus, to the cylindrical plexiglas respiration vessels of the type shown in Figure 1 (RoBerts 1961). A 24-hour adjustment period was found to suffice for carp, but sunfish generally have required from 48 to 72 hours. The ratio between fish and chamber volumes has ranged from 45 to 10 in these experiments (fish weight, 10-45 g). Partial darkening of the respiration vessels with black paint has been found to greatly reduce the excitability of both species and to minimize visual disturbances resulting from movements during procedures for obtaining water samples.

Opercular frequency. Within the last year, methods have been developed to record frequencies of opercular and cardiac cycles to serve as indicators of thermal and photoperiodic adaptation at different, more complex systemic levels of integration than is true for respiration. In both cases, the frequency recordings are obtained for

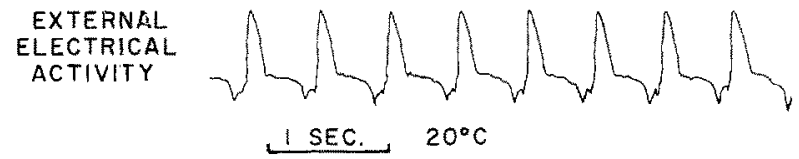

Fig. 2: Tracing of opercular signal detected external to sunfish, L. gibbosts

sunfish located either within the plastic respiration chambers or within troughs of similar dimensions and volume. Because few records of cardiac frequency have been obtained to date, the techniques and completed data will be reported elsewhere. The recordings of opercular rate (Fig. 2) have been obtained as repetitive and diphasic potentials of long period $(0.5-1.0 \mathrm{sec})$ between stainless-steel mesh electrodes attached 
to the front and back chamber walls, anterior and posterior to the fish (Fig. 1). These potentials are thought to be reflected to the recording system as changes in the resistance of the water shunting the electrodes with each spurt of water ejected from the branchial chamber of the fish as the opercular covers close. The potentials range from 20 to 400 microvolts and are dependent in magnitude upon the position of the fish in the chambers used. This view on the origin of the potential waves recently has been confirmed by Pasztor \& Kieneremoper (1962) who have detected similar potentials in their study of the role of the teleost gill filament musculature in gill ventilation.

\section{RESULTS}

\section{Adaptation by fish}

Respiration. Earlier I had reported that rates of respiration of fall and winter sunfish adapted to a 9-hour photoperiod were significantly higher than rates of fish maintained on a photoperiod of 15 hours at acclimation and test temperatures between $12^{\circ}$ and $20^{\circ} \mathrm{C}$ (ROBERTS 1961). However, more recent experiments have shown that the three-day acclimation periods used between each temperature drop $\left(2.5^{\circ} \mathrm{C}\right)$ were not sufficient to allow full thermal acclimation to the new temperatures. Therefore, the experiments have been repeated using acclimation periods of no less than 2 weeks. These results are illustrated in Figure 3 and indicate that there is a thermal range over which respiratory acclimation by non-breeding, male $L$. gibbosus is nearly perfect ( $Q_{10}$ about 1) or over which thermal homeostasis is maintained. This range (Fig. 3) is minimally $5^{\circ} \mathrm{C}\left(12.5^{\circ}\right.$ to $\left.17.5^{\circ} \mathrm{C}\right)$ for the two photoperiod groups. Because respiration rates of long-photoperiod animals are significantly lower (95 per cent confidence limits) than rates of animals on the 9-hour day at all temperatures above $10^{\circ} \mathrm{C}$, the results suggest that there is a leftward broadening in the range of homeostasis relating to adaptation to the 15-hour day. Also, there is an apparent greater degree of perfection in acclimation by this group as well. As in earlier experiments, the difference due to photoperiod has not been found with spring fish tested when in breeding condition (April to mid-August). During this period of the year, respiration rates determined at acclimation temperatures have been found to be the same as shown for the 9-hour fish in Figure 3. This is despite the length of the imposed photoperiod.

Values of $Q_{10}$ for the acclimated respiration rates of $L$. gibbosus, above and below the homeostatic temperature range, are as might be expected in acute experiments where rates are determined over a series of rapidly changed temperatures. Above the homeostatic range, $Q_{10}$ values for the two photoperiod groups are close to 2.0. Below, as is often to be expected (RAO \& Bullock 1954), the Q10 values are high, at 6.0 for the 15-hour fish and 6.3 for those on the 9-hour day.

Opercular frequency. The frequency of opercular movements also serves as a rate function which reflects metabolic acclimation by $L$. gibbosus, but less perfectly so than is the case for respiration (Fig. 4). Perhaps this is because there is a wide range in routine accomodation by such secondary metabolic processes as gill ventilation and circulation. For this reason, it is felt that simultaneous measures of both opercular and 


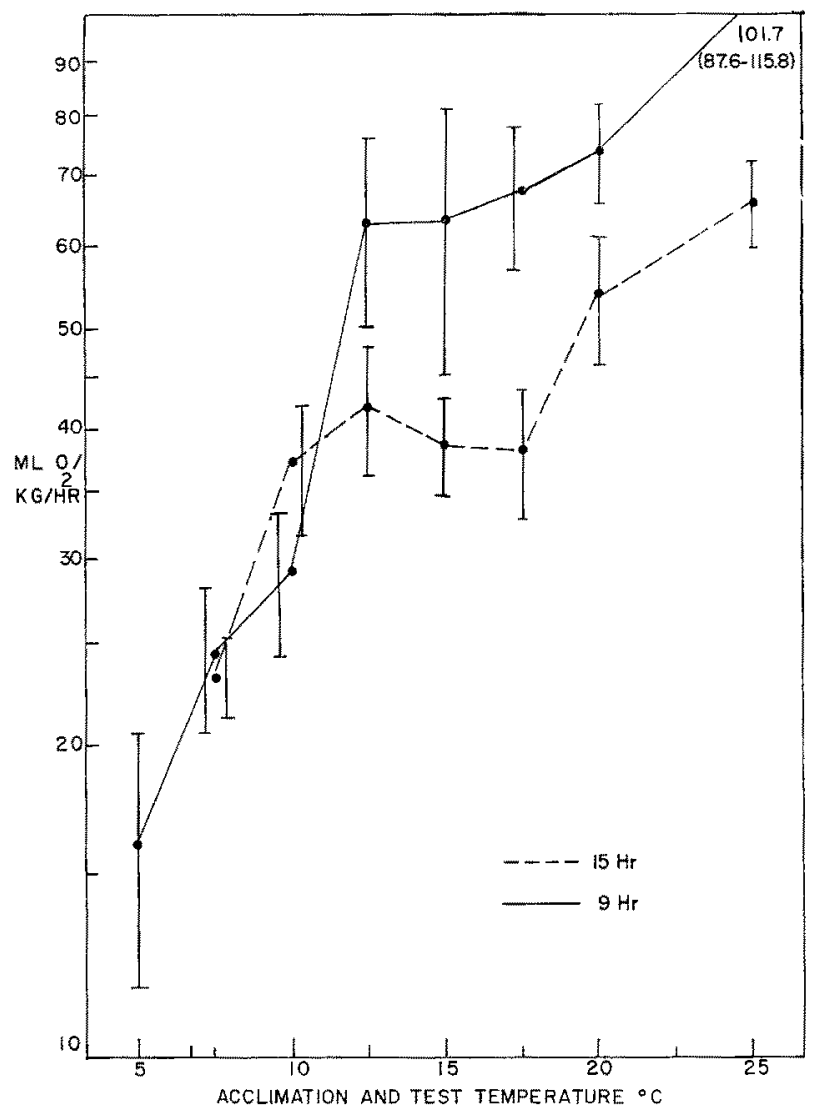

Fig. 3: Respiration tates of L. gibbostus at various acclimation temperatures and adapted to 9 and 15-hour photoperiods. Means $\bullet$ represent 12-15 animals each. Vertical bars indicate plus and minus 2 standard errors of means ( 95 per cent confidence limits). Temperature control $\pm 0.05^{\circ} \mathrm{C}$

cardiac frequencies may give a better appreciation of acclimation relative to the activity of secondary rate processes. Figure 4 also suggests that there may be photoperiod-related differences in opercular frequencies of the two groups below $10^{\circ} \mathrm{C}$ as well. Above $10^{\circ} \mathrm{C}$, the trend, paralleling results for respiration, is not supported statistically due to extreme variability in opercular frequencies between individual fish. This is due primarily to the fact that undisturbed sunfish vary individually in shifting between opercular and branchiostegial ventilation of the gills.

Individual variability in use of the two modes of ventilation at intermediate acclimation temperatures $\left(12.5^{\circ}\right.$ to $\left.20^{\circ} \mathrm{C}\right)$ generally indicates two patterns. Either an individual fish will seldom use branchiostegial ventilation or it will alternate between this mode and opercular ventilation. In the latter case, 10 to 15 opercular movements are followed by an equal time period consisting of branchiostegial movements at a higher frequency (shorter time base). This data has not been recalculated to determine if the opercular frequencies of these patterns are equivalent. However, shifts to bran- 


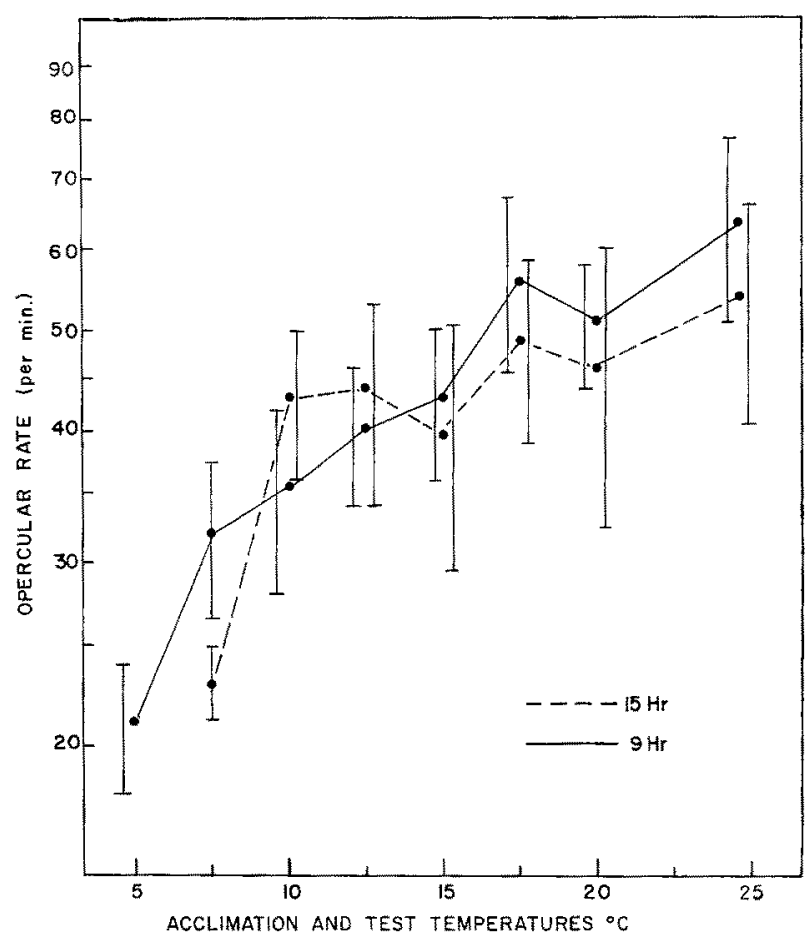

Fig. 4: Opercular frequencies of $L$. gibbosus at various acclimation temperatures and adapted to 9 and 15 -hour photoperiods. Symbols as in Figure 3. Temperature control $\pm 0.05^{\circ} \mathrm{C}$

chiostegial ventilation have least often been observed with short-day fish over the intermediate range in temperatures. This is indicated in Figure 4 as a smaller degree of variability in opercular frequencies for this group than is the case for fish on the longer photoperiod. This fact probably relates to the observations that respiration rates of the short-day fish are also the highest of the two photoperiod groups when acclimated to intermediate temperatures.

\section{Adaptations in tissues}

Rates of brain, gill, and muscle tissue respiration have been determined for $L$. gibbosus by standard Warburg manometry at $25^{\circ} \mathrm{C}$ (ROBERTs 1961). The media in use has been a fish saline (EKBERG 1958) containing $2.0 \mathrm{~g}$ per liter of sodium succinate and $2.5 \mathrm{~g}$ per liter of glucose, and adjusted to a $\mathrm{pH}$ of 7.4 with phosphate buffer. A limited number of studies also have been made utilizing liver tissue removed from sunfish of less than $15 \mathrm{~g}$ in weight. However, reasonable levels of oxygen uptake have been obtained only infrequently with liver samples removed from larger fish. Histological examinations of a number of livers have revealed the probable reason for this failure. In the larger fish (above $15 \mathrm{~g}$ ), the development of pancreatic tissue along the hepatic arteries and their branches is more extensive than in smaller fish. Therefore, it is likely 
that inactivation of liver cells in tissues from large fish occurs through the action of pancreatic enzymes.

No significant indications of photoperiod or temperature induced compensations of respiration on the succinate-glucose substrate have been detected for gill filaments, brain minces, or finely-minced muscle removed from $L$. gibbosus acclimated to $7.5^{\circ}$ and $20^{\circ} \mathrm{C}$ and the 9 and 15 -hour photoperiods. In contrast, following the addition of 2, 4-dinitrophenol (DNP) from the sidearms of the respiration vessels $\left(1 \times 10^{-4} \mathrm{M}\right.$, final concentration) to these same tissues, a very different pattern of uncoupled respiration was observed as given in Table 1 . The results for muscle (respiration levels about $0.05 \mathrm{ml} / \mathrm{gm} / \mathrm{hr}$ ) are not included in Table 1 for no response to the DNP was found.

Table 1

Respiration of brain minces and gill filaments of $L$. gibbosus at $25^{\circ} \mathrm{C}$ on a glucose-succinate saline before and after addition of 2,4-dinitrophenol. Sunfish adapted to photoperiods and temperatures indicated. Number of fish used for each experimental group, 15 or 16 . Plus and minus 2 standard errors of means shown in brackets below mean rates

\begin{tabular}{|lccccccc|}
\hline $\begin{array}{c}\text { Temperatures } \\
\text { and } \\
\text { photoperiods }\end{array}$ & \multicolumn{2}{c}{ brain ml/g/hr (wet wt.) } & \multicolumn{3}{c|}{ gill ml/g/hr (wet wt.) } \\
control & DNP & change & control & DNP & change \\
\hline $20^{\circ} \mathrm{C} \quad 15 \mathrm{hr}$ & 1.09 & 1.66 & +52 & 0.52 & 0.71 & +36 \\
& $(1.01-1.17)$ & $(1.59-1.73)$ & & $(0.47-0.57)$ & $(0.64-0.78)$ & \\
$20^{\circ} \mathrm{C}$ & $9 \mathrm{hr}$ & 1.14 & 1.91 & +68 & 0.54 & 0.82 & +52 \\
& $(1.08-1.20)$ & $(1.81-2.01)$ & & $(0.49-0.59)$ & $(0.76-0.88)$ & \\
$7.5^{\circ} \mathrm{C} \quad 15 \mathrm{hr}$ & 1.09 & 1.53 & +40 & 0.58 & 0.92 & +59 \\
& & $(1.03-1.15)$ & $(1.44-1.62)$ & & $(0.54-0.62)$ & $(0.85-0.99)$ & \\
$7.5^{\circ} \mathrm{C} \quad 9 \mathrm{hr}$ & 1.06 & 1.39 & +31 & 0.57 & 0.89 & +56 \\
& $(0.97-1.15)$ & $(1.28-1.50)$ & & $(0.51-0.63)$ & $(0.78-1.00)$ & \\
\hline
\end{tabular}

The uncoupling response of brain respiration to DNP appears to be greatest in the case of fish acclimated to the higher temperature of the two used and to the short photoperiod. Curiously, the response in change of respiration of the gill tissue to uncoupling by DNP appears to be reversed only with respect to the thermal history of the donor fish and not at all to photoperiod length. Preliminary results with brain and gill tissues utilizing a pyruvate-malate medium seem to confirm these results with the succinate-glucose substrate.

More recently, a modified medium containing equivalent amounts of sodium pyruvate and sodium malate buffered with TRIs (hydroxymethyl) aminomethane to the same $\mathrm{pH}$ has been substituted. This has been done to avoid possible inhibitory effects of high phosphate. Furthermore, the provision of an alternate substrate for succinate is considered to be more compatible with examination of possible photoperiod and temperature-induced adaptations in KREBS'-cycle and electron-transfer pathways. After screening a number of substrate combinations, the pyruvate-malate combination has been selected because it provides reasonable levels of respiration with the tissues in use, and minimizes the short-cycling effect of succinate oxidation by a flavin-linked dehydrogenase. In support of this latter consideration, a limited amount of evidence has been obtained with brain tissue. This indicates that a one-third greater uncoupling 
of oxygen uptake by DNP action occurs with the pyruvate-malate substrate than occurs with the succinate-glucose substrate.

\section{DISCUSSION}

Metabolic compensations by fish. In my introduction, I stated that full thermal compensation of metabolism by sunfish, Lepomis, seasonally is dependent upon concurrent exposure of the fish to seasonal day lengths. The results indicate that this is substantially correct for the pumpkinseed sunfish (L. gibbosus). Seemingly basic to the compensations by sunfish is the observation that there exists a critical temperature of about $10^{\circ} \mathrm{C}$ below which capacity adaptation (Leistungsadaptation, PreCHT et al. 1955) in rate functions appears to be absent and no significant sensitivity to day length is apparent. Above this temperature, but dependent upon whether or not the sunfish are in breeding preparation, a range in thermal homeostasis has been found over which metabolic or activity levels are sensitive to photoperiod.length.

The absence of capacity adaptation below $10^{\circ} \mathrm{C}$ does not preclude the probability that resistance adaptation (PRECHT et al. 1955) to cold occurs in L. gibbosus. It has been in fact demonstrated by BRETT (1956) for the related species, L. machrochirus, It is my view that this dual classification system of PrECHT for thermal compensations has proven useful, especially so, because there is considerable evidence that variations in rate functions used as acclimation (or adaptation) indices often are unrelated as between the two categories (BuLlock 1955). Furthermore, it seems likely that the genetic backgrounds for phenotypic expressions of these categories have been based on different modes of environmental selection.

The generality in the occurrence of critical temperatures as controlling factors for the induction of metabolic responses by fish to day length is questionable. I reported earlier (ROBERTS 1961), that the level of standard metabolism of a high-backed race of crucian carp (Carassius carassius) is photoperiod dependent, but only above a threshold temperature between $12^{\circ}$ and $20^{\circ} \mathrm{C}$. Very little other direct evidence is available, but most concerns seasonal breeding. For example, BAGGERMAN (1957) cites several cases which indicate that induction of spermiogenesis may be (Phoxinus laevis) or may not be (Gasterosteus aculeatus) subject to critical temperature levels.

In another context, $10^{\circ} \mathrm{C}$ is also critical as a lower controlling temperature for the successful maintenance of thermal homeostasis of respiration and opercular frequency by sunfish adapted to both 9 and 15-hour day lengths. Despite the fact that the homeostasis is less perfect for opercular activity $\left(Q_{10}\right.$ about 1.3), the results show that below $10^{\circ} \mathrm{C}$, relative homeostasis extends to a lower temperature under short-day adaptation than under long-day adaptation. Suggestive evidence for a similar coaction of temperature and photoperiod in the resistance adaptation of goldfish acclimated to $20^{\circ} \mathrm{C}$ has been provided by HOAR \& ROBERTSON (1959). They found that fish adapted to an 8 -hour day were more resistant to a cold stress than 16 -hour fish. Also as might be expected, the converse was found to be true with regard to heat stress.

The presence of homeostasis among poikilotherms has been frequently discussed, but with the recognition that clear examples of record are few (ButLock 1955, MEuw IS 


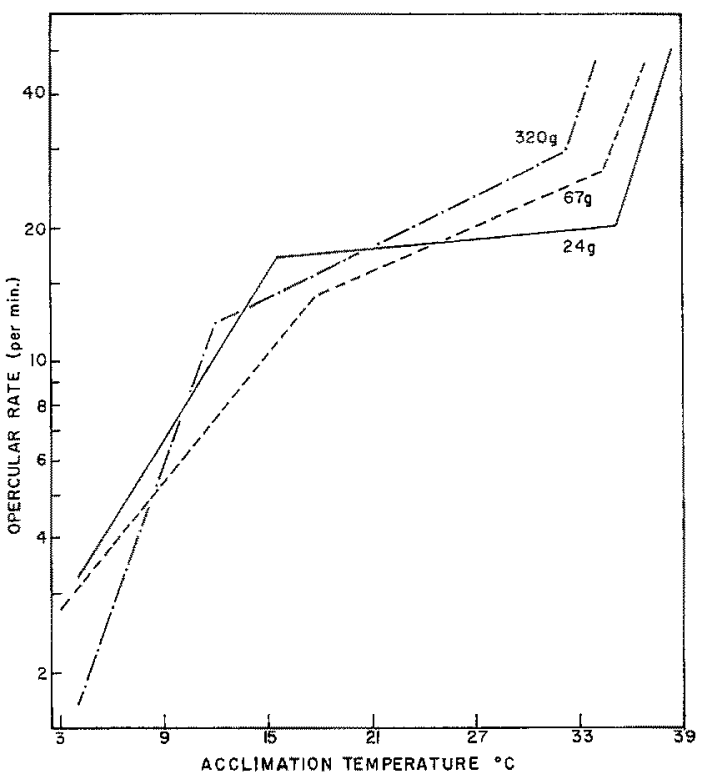

Fig. 5: Opercular frequencies of glass carp, C. carpio, of differing size at various acclimation temperatures (redrawn from MEUwis \& HeUTs 1957)

\& Heuts 1957, Precht 1958, Precht et al. 1955, Prosser 1962, Prosser \& Brown 1961). The breathing rate study (opercular frequency) with glass carp, Cyprinus carpio, by Meuwis \& Heuts (1957), is pertinent as a recent example. A portion. of this data is illustrated in Figure 5. Their experiments disclose that there is a wide range of homeostasis in this rate function which extends between upper and lower critical temperatures of $12.3^{\circ}$ and $34.5^{\circ} \mathrm{C}$. Further, they found the degree in perfection of thermal homeostasis to be a size dependent function (Fig. 5), decreasing in perfection (increasing $Q_{10}$ values) with increasing body size.

Comparisons of critical temperatures for the glass carp (Meuws \& Heuts 1957), my results with the crucian carp (RoBERTs 1961) and the sunfish data, indicate that the two cyprinid species are temperate warm-water fishes and the sunfish intermediate between this group and cold-water species (salmonoids). This is known to be the case for resistance adaptation of $C$. carpio (lethal temperatures, MEuwis \& Heuts 1957) and species closely related to C. carassius and L. gibbosus (Thermal Tolerance indices, BrETT 1956).

Earlier I suggested (ROBERTs 1961), as an explanation for the observed differences in levels of metabolism between sunfish adapted to long and to short days (short day higher), that adaptation to short day might serve to extend the feeding period in the fall by compensating for the seasonal decline in temperature. Under laboratory conditions, this species does not accept food at temperatures below $10^{\circ} \mathrm{C}$. Almost certainly, this type of compensation is of some ecological importance to the sunfish. It seems more probable, however, that the photoperiodic effect of inducing changes in metabolic rates, most directly relates to some process of conditioning the fish for their 


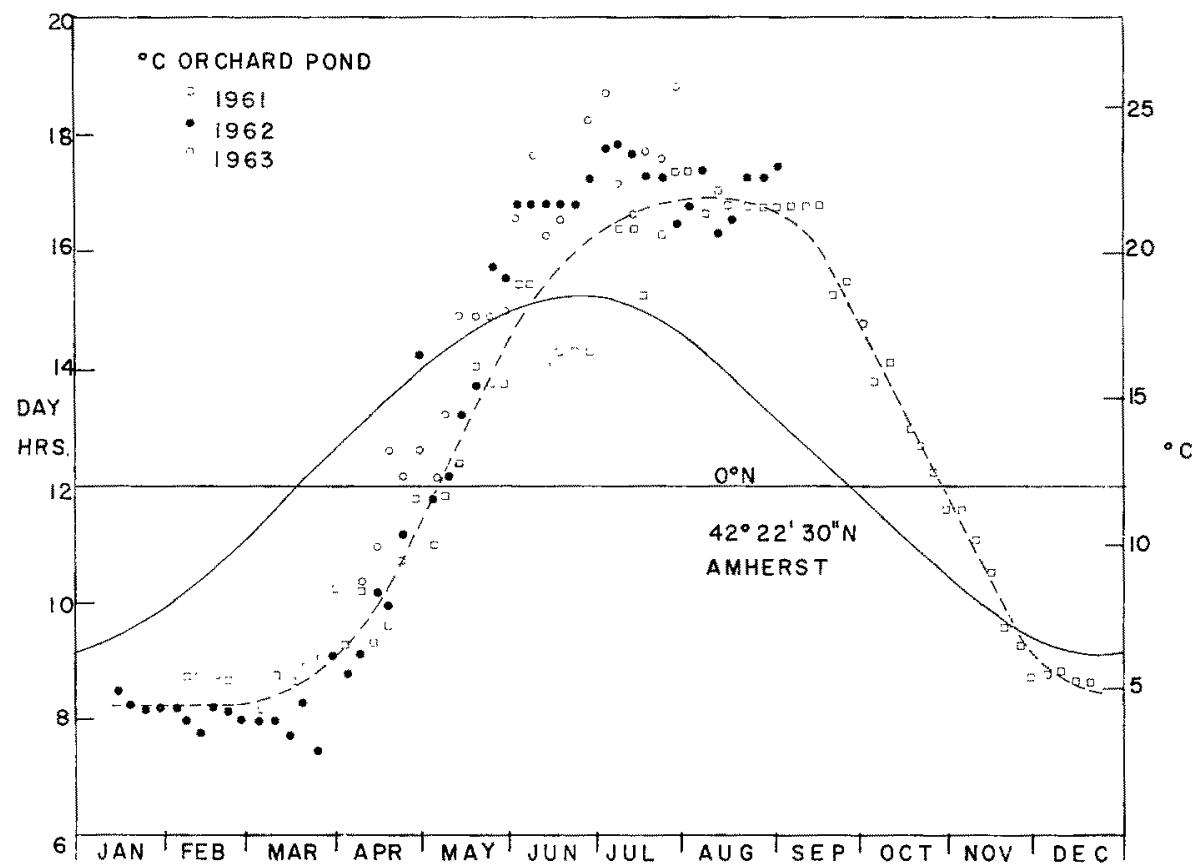

Fig. 6: Temperatures recorded over a 3-year period in a pond at 4-foot depth, Amherst, Massachusetts. Data points represent noon-day temperatures at 3-day intervals for different years. The dashed line (...) represents an eye-fitted average of temperatures. The solid line $(-)$ indicates day lengths between sunset and sunrise corrected for latitude to Amherst, Massachusetts (from The Nautical Almanac, 1962)

primary biological function, reproduction. Evidence significant to this view rests with my failure to obtain differences in respiration related to photoperiod manipulation with sunfish collected during spring. This indicated that once gonadal development begins, physiological sensitivity to the length of the daily photoperiod is lost until completion of breeding. Similarly, another consequence of the study by HoAR \& ROBERTSON (1959) was their observation that thermal tolerance limits of goldfish were labile to photoperiod except during spring. In addition, Harrington (1959) gives evidence of a developing refractoriness to external triggers (light and temperature) during the prespawning period of the minnow, Phoxinus phoxinus.

The exact timing for the induction of breeding preparation is not known for sunfish. Furthermore, it is not known whether temperature or photoperiod is the trigger for breeding of $L$. gibbosus in the spring. For purposes of speculation, I shall select temperature as the trigger. This is partly based on the observation that adaptation to the 9-hour photoperiod induces levels of respiration which are higher than rates of sunfish following 40 days exposure to a 16-hour day. It is also partly based upon temperature records which have been obtained in a holding pond for sunfish at Amherst from 1961 to the present. It can be seen in Figure 6 that in this pond, the temperature rises to $10^{\circ} \mathrm{C}$ within two months of the ice cover melt or near the end of April. Nesting behavior of the male sunfish may begin in late April also or in early May. This means 
that breeding preparation, if it is limited to a $10^{\circ} \mathrm{C}$ minimum, must be completed within no more than 2 weeks, unless it is already underway in the fall before the temperature drops below $10^{\circ} \mathrm{C}$. If not limited to a $10^{\circ} \mathrm{C}$ minimum, then the most logical conclusion would seem to be that the induction of the photoperiod-related difference in metabolism of the two groups adapted to long and to short day and the induction of seasonal breeding are unrelated events. However, this presents the problem of explaining in another way, the loss of photoperiodic sensitivity in respiration which has been found to be concurrent with seasonal breeding in the sunfish, L. gibbosus.

Metabolic compensations in tissues. The tissue respiration experiments I have presented represent only a small portion of a current study which is directed toward the possibility that thyroid activity may be intimate to temperature and photoperiod adaptations by sunfish. Therefore, my use of the data at the moment is in another context. In the case of L. gibbosus, differences in the respiration of tissues which relate to photoperiod and temperature adaptations, seem only to follow uncoupling with dinitrophenol. This response suggests that there are activity changes in some components of cellular systems, perhaps electron transfer, in various tissues which occur with adaptation to these physical factors and which become rate-limiting only after DNP uncoupling. In the case of C. carassius, I reported that gill and muscle demonstrate a positive acclimation to temperature (probably PRECHT's Type 3, RoBERTS 1961). Paradoxically, the reverse was found to be true for whole fish. They showed an inverse relation between acclimation temperature and rates of respiration. It is probable for C. carassius that systemic control, which in part has been found to be behavioral, can override respiratory responses to temperature which have been found in isolated tissues. The fact that the same metabolic systems in different tissues of the same species of fish may contrast so greatly as well as the same tissues in different species, makes it likely that systemic integration in varying degrees is important in the responses of fishes to changing temperatures and photoperiods (see also ProsSER 1962).

\section{SUMMARY}

1. Metabolic compensations by pumpkinseed sunfish, Lepomis gibbosus, to photoperiods of 9 and 15 hours and to acclimation temperatures ranging between $5^{\circ}$ and $25^{\circ} \mathrm{C}$ have been examined. Respiration rates of whole fish, their brain, gill and muscle tissues, and opercular frequencies were used as indices of adaptation. Techniques for the determination of respiration rates and opercular frequencies have been outlined and discussed.

2. A range in thermal homeostasis has been found for L. gibbosus over which thermal acclimation of respiration is nearly perfect ( $Q_{10}$ about 1 ), but which is modifiable by alterations in day length above $10^{\circ} \mathrm{C}$. Although less obvious, a relative thermal homeostasis has been detected for opercular frequency as well. Perfection of acclimation appears to be best with both indices in the groups of sunfish which have been adapted to the 15-hour photoperiod.

3. Significant differences in rates of respiration, but not in opercular frequencies, have been observed between the long and short-day groups of fall and winter sunfish 
above $10^{\circ} \mathrm{C}$. During spring and with sunfsh in breeding condition, these differences were not detected. Both short and long-day fish showed the same higher level of respiration found to be related to short photoperiod adaptation ( 9 hrs.). It is suggested that the photoperiodic effect of inducing changes in metabolic rates, most directly relates to some process of conditioning the fish for their primary biological function, reproduction.

4. Because the characteristics and photoperiod sensitivity of metabolic compensations for temperature by L. gibbosus are not apparent below $10^{\circ} \mathrm{C}$, this temperature is considered to be critical ecologically for the species in western Massachusetts. The existence of a lower critical temperature for thermal homeostasis of metabolic functions (capacity adaptation) in sunfish is stressed because of its potential as a sensitive indicator of physiological variations for climate and latitude.

5. No indications of compensation for photoperiod ( 9 and $15 \mathrm{hrs}$.) and temperatures $\left(7.5^{\circ}\right.$ and $20^{\circ} \mathrm{C}$ ) have been detected in the respiration of brain and gill tissues of L. gibbosus at $25^{\circ} \mathrm{C}$ except after uncoupling with dinitrophenol. The response of brain respiration with the drug appears to be greatest in sunfish adapted to a 9-hour day and $20^{\circ} \mathrm{C}$. In contrast, the dinitrophenol effect upon respiratory change of gill filaments appears to be reversed with respect to the thermal history of the donor fish (highest with acclimation to $7.5^{\circ} \mathrm{C}$ ), but unrelated to the length of the adaptation photoperiod. It is apparent that metabolic systems in different tissues of the same animal or the same tissues in different species, contrast greatly in compensatory responses to temperature and photoperiod. Therefore, the suggestion is offered that the resultant of systemic integration often may be more significantly reflected in responses of whole fishes to changing environmental factors than the possible direct effects of temperature sometimes seen in isolated tissues.

\section{ACKNOWLEDGMENTS}

It is a pleasure to express my debt for technical assistance to Dr. Sandra Durick Briel, Miss Nancy Kratowich, and Messrs. A. John Penicnak, Stephen Harrigan and Stephen StYRE.

\section{LITERATURE CITED}

BaGgerman, B., 1957. An experimental study of the timing of breeding and migration in the three-spined stickleback (Gasterosteus aculeatus L.) Arch. néerl. Zool. 12, 105-318.

- 1959. The role of external factors and hormones in migration of sticklebacks and juvenile salmon. Comparative Endocrinology, pp. 24-37, A. Gorbman, Editor. John. Wiley and Sons Inc., New York, 746 pp.

BLAŽKA, P., 1958. The anaerobic metabolism of fish. Pbysiol. Zoöl. 31, 117-128.

BRETT, J. R., 1956. Some principles in the thermal requirements of fishes. Quart. Rev. Biol. 31, 75-87.

BuLLOCK, T. H., 1955. Compensations for temperature in the metabolism and activity of poikilotherms. Biol. Rev. 30, 311-342.

EkвERG, D. R., 1958. Respiration in tissues of goldfish adapted to high and low temperatures. Biol. Bull., Woods Hole 114, 308-316. 
Evans, R.M., Purdie, F. C. \& Hickman, C. P. jr., 1962. The effect of temperature and photoperiod on the respiratory metabolism of rainbow trout (Salmo gairdneri). Can. J. Zool. 40, 107-118.

Fry, F. E. J., 1958. Temperature compensations. Annu. Rev. Physiol. 20, 207-224.

Harrington, R. W. jr., 1959. Photoperiodism in fishes in relation to the annual sexual cycle. Photoperiodism, pp. 651-668, R. B. Wrthrow, Editor, AAAS Symp. no. 55, Washington D. C., $903 \mathrm{pp}$.

HOAR, W. S., 1963. The endocrine regulation of migratory behavior in anadromous teleosts. XVI. Internat. Congr. Zool.; Proc. Spec. Symp. 3, 14-20.

- \& ROBERTSON, G. B., 1959. Temperature resistance of goldfish maintained under controlled photoperiods. Can. J. Zool. 37, 418-428.

Meuwis, A. L. \& Heuts, M. J., 1957. Temperature dependence of breathing rate in carp. Biol. Bull., Woods Hole 112, 97-107.

Pasztor, V. M. \& KLeERekoper, H., 1962. The role of the gill filament musculature in teleosts. Can. J. Zool. 40, 785-802.

PRECHT, H., 1958. Concepts of the temperature adaptation of unchanging reaction systems of cold-blooded animals. Physiological Adaptation, pp. 50-78, C. L. Prosser, Editor, Symp. Gen. Physiol. Am. Physiol. Soc., Washington D. C., 185 pp.

- Christopherson, J. \& Hensex, H., 1955. Temperatur und Leben. Springer-Verlag, Berlin, $514 \mathrm{pp}$.

Prosser, C. L., 1962. Acclimation of poikilothermic vertebrates to low temperatures. Comparative physiology of temperature regulation, II. Proc. Symp. on Arctic Biol. and Med., pp. 1-44.

- Barr, L. M., Pinc, R. D. \& Lauer, C. Y., 1957. Acclimation of goldfish to low concentrations of oxygen. Physiol. Zoöl. 30, 137-141.

- \& Brown, F. A. jr., 1951. Comparative Animal Physiology, 2ed. W. B. Saunders Co., Philadelphia, 688 pp.

RAO, K. P. \& BuLlock, T. H., 1954. Q10 as a function of size and habitat temperature in poikilotherms. Am. Nat. 88, 33-44.

RoBERTS, J. L., 1961. The influence of photoperiod upon thermal acclimation by the crucian carp, Carassius carassius (L.).Zool. Anz. (Suppl.) 24, 73-78.

\section{Discussion following the paper by ROBERTS}

WIEsER: Can a breeding cycle and a rise in $\mathrm{QO}_{2}$ be induced by artificial long day period at any time during the year?

RoserTs: We found that we could bring the fish into breeding earlier. I don't know the exact timing relationship here. We have not tried deliberately to bring fish just after completion of breeding back into breeding. We have not determined how long a period this would require. However, we do collect fish in very late summer or in early fall. These fish when exposed to long photoperiods will breed or will build nests in laboratory aquarium tanks in January.

WIESER: Is there a refractory period after the induction of a breeding cycle?

RoserTs: Yes. This is a problem. When we collect fall fish and try to measure their respiration rate after they show signs of breeding in the spring, we find that they fall along the same lines (Fig. 3) we would get with spring fish that are breeding or preparing to breed.

WIESER: A critical temperature threshold probably exists for breeding phenomena in all animals; in terrestrial species the additional effect might occur that the critical temperature has to prevail for a critical period of time.

RoBERTs: I think the experiments of Dr. BagGerman at Groningen show quite clearly that there is a very definite refractory period in the sticklebacks, and of course I think that the evidence is very good for the same in birds. The studies I know of Dr. Wolfson seem to be 
quite clear on this point, and it would seem that the same is also true of sunfish, but $I$ have not specifically studied this, so I cannot say.

SMITH: Thermogenesis may be increased by increased substrate turnover either accompanied or not by changes in the work function of the reactions involved. The over-all work function is decreased by thyroxine in vivo, and this may be reflected by a decrease in apparent $\mathrm{P} / \mathrm{O}$ ratio with homogenates or poorly washed mitochondria, but in the thyroxinized rat, at least, the $\mathrm{P} / \mathrm{O}$ of the well washed mitochondria is essentially normal. Thyroxine in vivo probably acts through its effects upon enzyme synthesis rather than by direct action upon the electron transfer system; hence its failure to raise metabolism of homogenates in vitro may well relate to the incapacity of such preparations for adequate protein synthesis.

ROBERTS: I have neglected to mention that we have been trying unsuccessfully so far to obtain mitochondrial preparations. I agree that to obrain meaningful "work function" for adapted organisms we must be able to determine if adaptive changes may occur in mitochondria (e. g. $\mathrm{P} / \mathrm{O}$ ratios).

PRECHT: Das Versuchstier mit einem kleinen Intervall der Leistungsadaptation wäre geeignet, zu prüfen, ob auch die Resistenzadaptation ähnliches zeigt, um das Problem der gemeinsamen Ursachen zu klären.

RoBERTS: In separating the adaptation types as to genetic background, I want to make clear that I am speaking only of what might be considered possible genetic adaptations to climate well within the limits for resistance adaptation. 